\title{
Zingevers : een introspectieve
}

Citation for published version (APA):

van Praag, H. M. (1997). Zingevers : een introspectieve. Van Gorcum \& Comp. B.V. https://doi.org/10.26481/spe.19970606hp

Document status and date:

Published: 06/06/1997

DOI:

10.26481/spe.19970606hp

Document Version:

Publisher's PDF, also known as Version of record

\section{Please check the document version of this publication:}

- A submitted manuscript is the version of the article upon submission and before peer-review. There can be important differences between the submitted version and the official published version of record.

People interested in the research are advised to contact the author for the final version of the publication, or visit the DOI to the publisher's website.

- The final author version and the galley proof are versions of the publication after peer review.

- The final published version features the final layout of the paper including the volume, issue and page numbers.

Link to publication

\footnotetext{
General rights rights.

- You may freely distribute the URL identifying the publication in the public portal. please follow below link for the End User Agreement:

www.umlib.nl/taverne-license

Take down policy

If you believe that this document breaches copyright please contact us at:

repository@maastrichtuniversity.nl

providing details and we will investigate your claim.
}

Copyright and moral rights for the publications made accessible in the public portal are retained by the authors and/or other copyright owners and it is a condition of accessing publications that users recognise and abide by the legal requirements associated with these

- Users may download and print one copy of any publication from the public portal for the purpose of private study or research.

- You may not further distribute the material or use it for any profit-making activity or commercial gain

If the publication is distributed under the terms of Article $25 \mathrm{fa}$ of the Dutch Copyright Act, indicated by the "Taverne" license above, 
Universiteitsbibliotheek

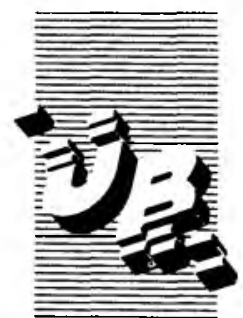

De uitleentermijn verstrijkt op:

29 julitgil

$5+50203$

Universiteit Maastricht

Postbus 616

6200 MD Maastricht

Gelieve deze publicatie tijdig te retourneren of (telefonisch) verlenging van de uitleentermijn aan te vragen.

UNIVERSITEITSBIBLIOTHEEK RU LIMBURG 
PROF.DR, H.M. VAN PRAAG

\section{Zingevers}

Een introspectieve

\section{Voordracht}

bij het afscheid als hoogleraar psychiatrie aan de Universiteit Maastricht op

6 juni 1997.

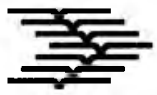

1997

van Gorcum 
Alle rechten voorbehouden. Niets uit deze uitgave mag worden verveclvoudigd, opgeslagen in cen geautomatiseerd gegevensbestund, of openbaar gemaakt, in enige vorm of op enige wij\%e, hetzij elektronisch, mechanisch, door fotokopicen, opnamen, of enig andere manier, zonder voorafgaande schriftelijke toestemming van de uitgever.

Voor zover het maken van kopicen uit deze uitgave is toegestaan op grond van artikel 1613 Autcurswec $1912 \mathrm{j}^{\mathrm{j}}$, het Besluit van 20 juni 1974, St.b. 351, zoals gewijzigd bij het Besluit van 23 augustus 1985, St.b. 471 en artikel 17 Autcurswet 1912, dient men de claarvoor wettelijk verschuldigde vergoedingen te voldoen aan de Stichting Reproreche (Postbus 882, $1180 \mathrm{AW}$ Amstelveen). Voor het overnemen van gedeclte(n) uit deze uitgave in bloemlezingen, teaders en andere compilaticwerken (artikel 16 Auteurswet 1912) dient men zich to de uitgever te wenden.

ISBN 9023232593

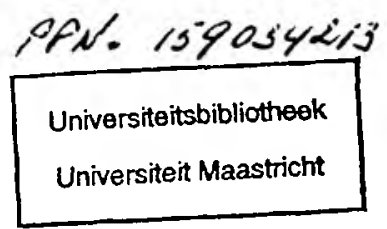

Grafische verzorging: Van Gorcum, Assen 
In what dimension of existence does man become aware of the grandeur and earnestness of living? What are the occasions in which he discovers the nature of his own self? The necessity to diagnose and to heal the condition of the soul? In the solitude of self-reflection the self may seem to be a fountain of beautiful thoughts and ideals. Yet thought may be a spell, and ideals may be worn like borrowed diadems.

It is in deeds that man becomes aware of what his life really is, of his power to harm and to hurt, to wreck and to ruin; of his ability to derive joy and to bestow it upon others; to relieve and to increase his own and other people's tensions. It is in the employment of his will, not in reflection, that he meets his own self as it is; not as he should like it to be. In his deeds man exposes his immanent as well as his suppressed desires, spelling even that which he cannot apprehend. What he may not dare to think, he often utters in deeds. The heart is revealed in the deeds.

Abraham Joshua Heschel (1955) 


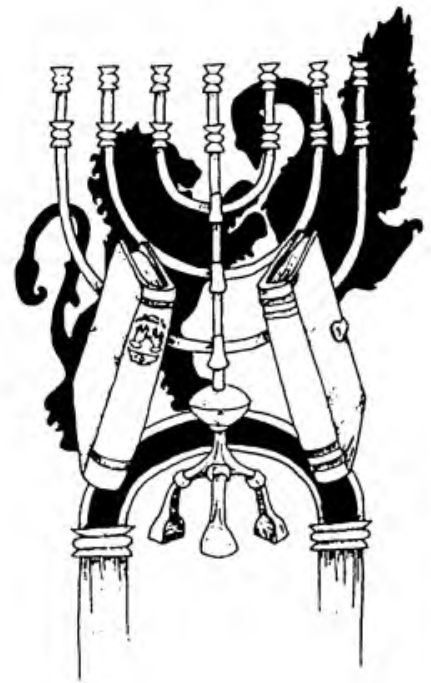

Aan de nagedachtenis van mijn ouders Aan mijn gezin. 


\section{INHOUD}

I Heeft het zin gehad

2 Eerste zingever: het gezin Io

3 Tweede zingever: de studie 13

3.I Drijfveren 13

3.2 Enkele wetenschappelijke activiteiten $\quad 15$

3.3 Enkele organisatorische activiteiten 24

$\begin{array}{ll}3.4 \text { De lof van het presteren } & 27\end{array}$

4 Derde zingever: het Jodendom 29

4.1 Het principe $\quad 29$

4.2 De praktijk 31

5 Epiloog 33

$\begin{array}{ll}\text { Noten } & 35\end{array}$

$\begin{array}{ll}\text { Literatuur } & 38\end{array}$ 


\section{Heeft het zin gehad}

Dat is het dan geweest. Ik markeer vandaag het officiële einde van een academisch gerichte loopbaan die zich over een periode van ongeveer 45 jaar heeft uitgestrekt. Het beginpunt ligt in I952 toen ik als medisch student, onderzoeksassistent werd bij Prof. dr. G.G.J. Rademaker, de toenmalige hoogleraar neurologie in Leiden. De neurologische onderzoeksperiode werd gevolgd door een mycologische. Als militair arts kreeg ik het verzoek een onderzoek te doen naar het voorkomen, de behandeling en de preventie van schimmelaandoeningen bij militairen. Ik werkte gedurende ruim I.5 jaar op de afdeling Medische Mycologie van het Fytopathologisch Laboratorium te Baarn, een inter-universitair instituut van de Universiteiten van Amsterdam en Utrecht'. Direct na m'n militaire diensttijd, begin I958, werd ik assistent psychiatrie en begon met psychiatrisch onderzoek. De psychiatrische onderzoeksperiode heeft tot op deze dag voortgeduurd, zij het op wisselende locatie: Rotterdam, Groningen, Utrecht, New York en tenslotte Maastricht.

Zo ergens, dan is dit een punt in iemands leven dat vraagt om een terugblik, een retrospectieve. Heeft het allemaal zin gehad en zo ja wat waren de zingevers? De eerste vraag beantwoord ik bevestigend; ik heb m'n leven als zinvol ervaren. De tweede vraag, die naar de zingevers, wil ik vandaag met $u$ bespreken. Mijn afscheidsrede is een introspectieve, meer dan een retrospectieve. Dit betekent dat mijn betoog een heel persoonlijk karakter draagt. U zou van een psychiater niet anders verwachten. Een onpersoonlijk psychiater is een professionele karikatuur. 
Welnu, mijn leven heeft drie zingevers gehad. Ze zijn het nog en zullen het blijven: gezin, studie, Jodendom. De betekenis die ze voor mij hebben, leg ik nu aan u voor'.

\section{$2 \quad$ Eerste zingever: het gezin}

Ons gezin is voor mij de kern-zingever. Aan deze zingever ontlenen de twee andere - studie en Jodendom - hun status. Alléén bestaan, zou voor mij alleen staan hebben betekend, een bestaansvorm die ik als zinloos zou hebben ervaren. Het gezin is in mijn leven klankbord en krachtbron geweest.

Mijn vrouw heeft, al meer dan 40 jaar mijn leven verlicht, in de dubbele betekenis van dit woord. Je ontlastte me, Nelleke, wanneer ik onder druk stond en liet licht op mijn bestaan vallen, zodat het diepte en kleur kreeg. We zijn onder huwelijkse voorwaarden getrouwd, maar het is een huwelijk in gemeenschap van gevoelens geworden. Een waarachtig "marriage des emotions". Er is tussen ons een twee-eenheid gegroeid waardoor mijn bestaan fundamenteel is verrijkt. Je bent de voornaamste zingever van mijn bestaan. Mijn dank hiervoor is niet meer dan rudimentair in woorden uit te drukken.

De (klein-)kinderen belichamen het continuiteits-beginsel in mijn leven, het perspectief naar voren. In hen lost zich de schaduw op die de vergankelijkheid op het leven werpt.

Ik heb mijn gezin hoog en hecht - meer algemeen gezegd grote waarde aan het gezin als grondstructuur, als bouwsteen van een humane, dat is een op verdraagzaamheid en onderling respect, gefundeerde samenleving. Een humane samenleving vertoont bepaalde kenmerken. De leden zijn bereid voor elkaar verantwoordelijkheid te dragen en te nemen. Ze hebben geleerd elkaar in hun waarde te laten. Ze hebben ervaren dat vreugde en verdriet, voorspoed en rampspoed, gedeeld kunnen worden en daarmee aan intensiteit winnen, respectievelijk inboeten. Ze zijn bereid en in staat eigen belang ondergeschikt te maken aan 
een algemeen belang; om bepaalde intenties na te laten ter wille van de ander; om behalve te nemen ook te kunnen geven. Voor het verwerven en beproeven van die eigenschappen is het gezin m.i. een optimale leerschool en proeftuin.

Niet elk gezin verschaft die basisopleiding. Er zijn gezinnen, waar onderlinge zorg en respect ontbreken en ik erken dat deze mogelijk een voedingsbodem kunnen zijn voor onverdraagzaamheid en egotisme. Deze constatering ontkracht mijn betoog niet. Ik stel niet, dat slechte verhoudingen in een intact gezin te prefereren zijn boven de misère veroorzaakt door een gebroken gezin. Wat ik beklemtoon is, dat het de moeite loont actief te streven naar gezonde gezinsverhoudingen. Ten eerste omdat deze een positieve weerslag hebben op de kwaliteit van een samenleving. Ten tweede, omdat die pogingen, aan hen die pogen, een voldoening schenkt die niet uitblust, z'n intensiteit behoudt en onvergelijkelijk is in kwaliteit. Als analogie: men laat het systeem van de sociale zekerheid niet varen, omdat er gevallen zijn waarin dat systeem misbruikt wordt.

Mijn opvatting in deze, geldt in kringen die zich progressief noemen als oubollig, eng, muf, duf, bekrompen, conventioneel, burgerlijk zo niet kleinburgerlijk; getuigend van een reactionaire geest. Ter illustratie, één voorbeeld. Ik citeer Bas Blokker die op 19 juli 1995 in de NRC de reprise besprak van David Lean's beroemde film Brief Encounter. Deze film verhaalt van een man en een vrouw, beiden getrouwd, en zeker niet ongelukkig getrouwd, die een relatie aangaan. Een kortstondige relatie, omdat zij besluiten weer uit elkaar te gaan, ter wille van hun partner en hun kinderen. De recensent merkt op: "De film eindigt als een eerbetoon aan het conformisme, aan het geduldig dragen van het lot, aan de kleinburgerlijke conventies. En het zou dus een ideale film zijn om je aan te ergeren, als-ie niet zo mooi was".

Ik ben het met Blokker eens, dat de film bijzonder mooi is. Ik deel zijn opvatting dat zij een eerbetoon is aan het conformisme. Ik verwerp zijn opvatting, dat het bewuste streven om zich 
aan bepaalde ethische gedragsregels te conformeren en te pogen deze in praktijk te brengen, kleinburgerlijk is. Het is burgerlijk gedrag, in de meest nobele zin van dit woord: de zin van fatsoenlijk gedrag. Het is gedrag dat een samenleving verrijkt en verdient derhalve het predikaat progressief. Alleen via een conceptuele travestie waarin de begrippen progressief en reactionair worden verwisseld, komt men tot de omgekeerde conclusie. "Decency", "honnêteté", "Anständigkeit" zijn begrippen met een nobele klank. In het Nederlands werd het begrip fatsoenlijk voorzien van een minusteken. Dit is weliswaar radicaal - een geliefkoosd begrip bij hen die zich vooruitstrevend noemen maar het is radicalisme van het verkeerde soort, het is reactionair radicalisme.

Ik beroep me met deze opvatting (mede) op de empirie (o.m. Mc Lanahan and Sandeful, I994; Thomson and Kaplan, 1996). Het gebroken, c.q. dysfunctionerende gezin kan een voedingsbodem zijn voor stoornissen in de persoonlijkheidsontwikkeling en vermindert zo de kans op een succesvolle "pursuit of happiness". Zelfrespect en zelfvertrouwen bijvoorbeeld zijn attributen die in sterke mate in en door het primaire milieu worden gemodelleerd. Suboptimale gezinsverhoudingen in de jeugd en het voorkomen van gestoorde (gezins-)relaties op latere leeftijd zijn dan ook sterk gecorreleerd.

Het opgroeien in een onvolledig of dysfunctionerend gezin is een risico factor voor, allerminst de oorzaak van stoornissen in de persoonlijkheidsontwikkeling. Het is bovendien geen noodzakelijke voorwaarde. Evenals gebrek aan lichaamsbeweging een risicofactor is voor het krijgen van een hartinfarct, zo stellen McLanahan en Sandefur (1994), maar vele niet-sportieven nooit een hartinfarct krijgen, zo leiden velen die opgegroeid zijn onder suboptimale omstandigheden later toch een bevredigend en produktief bestaan. Niettemin, risicofactoren zijn er om te worden vermeden.

Ik stel derhalve, dat de "good old family values" een bijdrage leveren tot ontplooiing van de persoonlijkheid; dusdoende tot 
harmonisering van intermenselijke betrekkingen en zo uiteindelijk tot optimalisering van maatschappelijke verhoudingen; tot wat in het Joodse denken Tikkun Olam wordt genoemd: het helen, het genezen van de wereld. Hun invloed is heilzaam voor een samenleving en het praktiseren ervan, volgens mijn definitie van die begrippen, derhalve progressief, niet reactionair. Nogmaals, met de door mij gewraakte opvatting wordt het predikaat progressief verleend aan gedrag dat mentaal consumptief en egocentrisch is, terwijl gedrag dat zelf-beperkend en altruistisch is als conservatief wordt afgedaan. Een waardeoordeel wordt op z'n kop gezet. Het is niet het enige voorbeeld hiervan in onze moderne samenleving.

Valt er op mijn opvatting iets af te dingen? Misschien wel, maar het doet in dit verband niet ter zake. Het gaat in deze toespraak primair om mijn bestaan en om mijn waarden, niet om algemeenheden. Ik constateer dat voor mij persoonlijk, die gezinswaarden het plechtanker van mijn leven zijn geweest.

\section{Tweede zingever: de studie}

\section{I Drijfueren}

Studie is een tweede zingever in mijn leven geweest en is dat nog steeds. Zonder dat, zou in mijn leven onderdruk heersen. Studiezin werd niet in de eerste plaats gevoed door eerzucht of door maatschappelijke aspiraties. Evenmin was het een vlucht uit en voor oorlogsherinneringen, zoals psychoanalytici mij wilden doen geloven. Er waren andere krachtige drijfveren.

Allereerst, diepgaande belangstelling voor het lichaam/ziel vraagstuk, moderner: voor het hersenen- en gedragsprobleem. Ik was van mijn middelbare schooljaren af, gefascineerd door de vraag hoe de "substantie" die wij gedrag en beleven noemen, samenhangt met de functionele toestand van bepaalde hersensystemen. Een andere drijvende kracht was de behoefte iets 
nieuws voort te brengen. Tot aan mijn kandidaarsexamen had ik literaire ambities. Ik schreef essays, verhalen, gedichten en was verschillende jaren literair redacteur van Forum Academiale, destijds het interuniversitaire studentenblad. Ik gaf die ambitie op ter wille van een wetenschappelijke loopbaan, nadat ik als student onderzoek was gaan doen bij Prof. Rademaker.

En tenslotte, het ongekende boeit me. Ik reis graag, letterlijk en figuurlijk. Ik zie graag nieuwe dingen. Studeren is voor mij het ondernemen van een ontdekkingsreis; het belopen van een nieuw traject, beginnend bij onkunde en lopend via kennis naar deskundigheid. Meestal worden paden bewandeld die reeds door anderen zijn gebaand; soms lukt het nieuwe wegen uit te zetten naar bekende bestemmingen; een enkele maal heeft men het geluk een nog onbekend domein open te leggen. Zo werden mijn werkkamer, de bibliotheek, het laboratorium tot onovertroffen reisbureaus.

Hebben mijn expedities naar nieuwe uitzichtspunten geleid? Het is de kernvraag die iedere onderzoeker zich regelmatig stelt en a fortiori bij zijn officiële afscheid. Onderzoek vereist grote investeringen aan tijd, aandacht, en energie. Men moet er veel voor opgeven. Is het, achteraf gezien, de moeite waard geweest?

Ik meen van wel en al zijn zelf-beoordelingen bijna per definitie voor-oordelen, ik waag het er toch maar op enkele vista's te schetsen die door het werk van mij en mijn medewerkers zijn opengelegd en waarvan ik meen dat zij totdien onscherp te zien of ongezien waren. $\mathrm{Zij}$ hebben met name betrekking op drie gebieden: biologische determinanten van affectieve stoornissen; klinische diagnostiek en meting van deze ziektebeelden en, als derde: grondslagen van de psychiatrische diagnostiek.

Deze gebieden hangen nauw samen. Biologisch onderzoek in de psychiatrie veronderstelt zorgvuldige diagnostiek en zorgvuldige diagnostiek vereist dat psychiatrische ziektebeelden op adequate wijze in kaart zijn gebracht en op valide en betrouwbare 
wijze kunnen worden gemeten. Zwakte in één van die schakels ondergraaft de waarde van de totale research inspanning.

\subsection{Enkele wetenschappelijke activiteiten}

\section{Diagnostiek}

Een eerste speerpunt van mijn onderzoeksprogramma over de jaren was de psychiatrische diagnostiek. Die was jarenlang chaotisch, want niet gestandaardiseerd of geoperationaliseerd. Diagnostische criteria werden bepaald door privé opvattingen, die "school" maakten. Met enige, maar niet veel overdrijving kan men zeggen, dat er evenveel diagnostische systemen als leerboeken waren. Deze situatie maakte wetenschappelijk onderzoek in de psychiatrie onmogelijk en dat was nu juist wat ik wilde gaan doen.

Toen ik mijn assistentschap in de psychiatrie begon - het was begin 1958 - waren de antidepressiva net geïntroduceerd. Zij paarden een markant therapeutisch effect bij sommige vormen van depressie, aan een invloed op bepaalde chemische prikkeloverdragers in de hersenen. Dit gold met name die groep van chemische stoffen, die monoaminen worden genoemd. Ik vond dit een revolutionaire ontwikkeling en vroeg me twee dingen af:

I hangt het therapeutische effect van antidepressiva samen met hun invloed op de monoaminen in de hersenen, en

2 zijn er bij depressieve patiënten die gunstig reageren op antidepressiva, afwijkingen aantoonbaar in zenuwbanen die monoaminen als prikkeloverdrager gebruiken en oefenen antidepressiva hierop een regulerende werking uit (Van Praag, 1962). Het zijn vragen die mij tot op deze dag bezig houden.

Ik was ervan overtuigd, dat onderzoek van deze aard nauwgezette definiëring van depressieve ziektebeelden vereist. De consequentie van deze overweging was, dat wij als eersten een gestandaardiseerde en geoperationaliseerde depressie diagnos- 
tiek ontwikkelden en toepasten* dat wil zeggen een diagnostiek die geënt is op precieze en verifieerbare definities. Binnen de gevestigde psychiatrie - en met name binnen de psychoanalytische en fenomenologische richtingen - wekte deze strategie ergernis op. Psychiatrische ziektebeelden werden als bij uitstek de "allerindividueelste expressie van de allerindividueelste emotic" gezien. Objectivering en psychiatrisch diagnostiseren werden beschouwd als onverenigbare grootheden. Validiteitsonderzoek van diagnostische constructies was in de psychiatrie een onbekend verschijnsel.

Twintig jaar later werd onze strategie overgenomen in de derde editie van de DSM, de moderne taxonomie van psychiatrische ziektebeelden die in kringen van psychiatrische researchers en practici vrijwel algemeen wordt aanvaard.

\section{Meting}

Onderzoek naar de neurobiologische grondslagen van gestoord menselijk gedrag vereist niet alleen nauwkeurige en overdraagbare diagnostiek, maar evenzeer methoden om de gedragscomponenten waarvan men de biologie wil bestuderen, te meten. Dergelijke methoden waren in de tijd toen ik mijn onderzoek begon, nauwelijks voorhanden. De ontwikkeling van schalen waarmee een beoordelaar een schatting kan geven van de ernst van een bepaald psychopathologisch verschijnsel was net begonnen. Wij overwogen of het niet mogelijk was het instrument dat de psychiater hanteert, i.c. het interview, te de-subjectiveren en overdraagbaar te maken. Dit idee resulteerde in het eerste

* Ik gebruik van nu af aan de wij-vorm, niet als pluralis majestatis, maar om aan tc geven dat mijn werk over de jaren in samenwerking met vele voortreffeljkc collegac werd verricht. Ik noem, zonder volledig te zijn, uit mijn Rotterdamse periode: mensen als Leijnse, Uleman, Spitz en Van Scheyen; uit Groningen: Korf, Van den Hoofdakker, Dijkstra, Bouhuys en Schut; uit Utrecht: De Wied, Van Ree, Verhoeven en Westenberg; uit New York: Asnis, Kahn, Zukin, Katz, Wetzler, Plutchik en Papolos en uit Maastricht: Jolles, Honig, Verhey Jr., Griez, Van Os en De Vries. 
gestandaardiseerde en geoperationaliseerde interview dat in de psychiatrie werd geïntroduceerd, het zogeheten Interview Vitaal Syndroom (Van Praag et al, 1965). Vanaf het midden van de zeventiger jaren zou deze methode in de psychiatrische research algemeen worden toegepast.

Samen met experimentele, klinische psychologen ben ik mijn gehele loopbaan blijven werken aan optimalisering van de meting van gestoord gedrag (o.m. Plutchik en Van Praag, I987; Plutchik et al, I989; Apter et al, I991; Van Praag, I992a).

Nosologische scepsis

Ook de validiteitsproblemen waarvoor de psychiatrische diagnostiek zich gesteld ziet, hebben mij nooit meer losgelaten (Van Praag, 1996b). In 1980 werd, zoals gezegd, de eerste geoperationaliseerde en gestandaardiseerde taxonomie van psychiatrische aandoeningen geïntroduceerd. $\mathrm{Zij}$ werd vrijwel onmiddellijk door de wetenschappelijke psychiatrische wereld omarmd. Mijn oordeel was ambivalent. Het principe van diagnostische uniformering juichte ik uiteraard toe. Over de theoretische uitgangspunten had ik echter ernstige twijfels. Ik vroeg mij af, of de premissen waarvan werd uitgegaan wel juist waren; of deze premissen wetenschappelijke vraagstellingen verduidelijken of juist verdoezelen (o.m. Van Praag ig82a, 1982b). Ik verklaar mij nader.

De psychiatrie is in de afgelopen ıo jaar sterk beïnvloed door het nosologische denken. De officiële psychiatrische taxonomie weerspiegelt dit. De nosologische visie veronderstelt het bestaan van goed afgrensbare en van elkaar te onderscheiden psychiatrische ziekten, ieder voor zich gekenmerkt door bepaalde ziekteverschijnselen, een bepaalde ziekteoorzaak en een bepaald ziekteverloop. Tussen deze drie grootheden wordt geacht een voorspelbaar verband te bestaan. Met andere woorden: met een diagnose als b.v. schizofrenie, depressie in engere zin of paniekstoornis, zijn de symptomen van een patiënt, het verloop 
van de ziekte en het behandelingsresultaat met vrij grote zekerheid vastgelegd.

Het was deze premisse waarvan ik de juistheid betwijfelde. Voorspelbare verbanden tussen symptomen, mogelijke oorzaken en verloop kon ik niet aantonen. In de praktijk bleken de meeste patiënten combinaties te vertonen van discreet geachte ziektebeelden of van gedeelten daarvan. Zij voldeden b.v. aan de criteria voor een bepaald soort depressie, een bepaalde angststoornis, een verslavingsziekte, en van één of meer persoonlijkheidsstoornissen. Voorspellingen over verloop bleken onbetrouwbaar. Bovendien konden wij weliswaar biologische afwijkingen aantonen bij psychiatrische patiënten, maar de aanof afwezigheid ervan bleek niet te gecorreleerd te zijn met het al dan niet voorkomen van een bepaalde nosologische diagnose (o.m. Van Praag et al, 1987a).

\section{Reactievormen}

Op grond hiervan begon ik serieus een ander diagnostisch model te overwegen: het zogenoemde reactievorm model. Volgens dat model bestaan er geen afzonderlijke, van elkaar goed af te grenzen en als zodanig herkenbare psychiatrische ziekten, maar op z'n hoogst ziekte-"bassins": groepen van op elkaar lijkende, maar in feite heterogene aandoeningen (o.m. Van Praag en Leijnse, 1965; Van Praag et al, 1975, 1990; Van Praag, 1992a, I992b, 1996a).

Deze opvatting gaat er van uit, dat de onderscheidene ziekmakende factoren (biologisch dan wel psychologisch van aard; genetisch bepaald dan wel tijdens het leven verworven), via verstoring van de functie van bepaalde hersensystemen, bepaalde psychologische functies ontwrichten. De mate waarin de verschillende hersencircuits worden ontregeld is echter individueel variabel en wordt bepaald door zulke factoren als: aard van de noxe of het samenstel van noxen; constitutioneel zwakke schakels in een bepaald zenuwcircuit; de mogelijkheden om een bepaalde neuronale ontregeling te compenseren. De psychopa- 
thologie die met de uiteindelijke neuronale ontregeling correspondeert varieert dientengevolge van patiënt tot patiënt. Men kan derhalve niet spreken van discrete ziekten; op z'n hoogst van groepen -- "bassins" - van aandoeningen die enige symptomen met elkaar gemeen hebben maar qua uitlokkende factoren en qua cerebrale grondslagen heterogeen zijn. Uitgaande van dit diagnostische model, zijn voorbeelden van dergelijke "bassins": de groep van de stemmingstoornissen, de groep van de dementiële en die van de psychotische aandoeningen.

"Bassins" van psychiatrische toestandsbeelden, zijn overdrachtelijk gesproken, te vergelijken met wolken in de lucht: men herkent de wolk; de vorm ervan wisselt echter van moment tot moment en van wolk tot wolk.

\section{Functionele psychopathologie}

Het reactievorm model heeft twee belangrijke consequenties, één voor het diagnostiseren, één voor het biologisch onderzoek van psychiatrische aandoeningen. Bij het diagnostiseren van psychiatrische toestandsbeelden kan niet worden volstaan met het aanduiden van een bepaalde ziekte, b.v. depressie of schizofrenie - want die worden geacht "bassins" te zijn van heterogene aandoeningen - en evenmin met de beschrijving van het syndroom, aangezien vele patiënten verschijnselen vertonen die behoren bij verschillende syndromen.

Diagnostiek van psychiatrische aandoeningen vereist daarenboven en bovenal: nauwkeurige karakterisering en meting van de psychologische functies die in een bepaald geval gestoord zijn. In het geval van een depressief toestandsbeeld noem ik, als voorbeelden, stoornissen in de informatieverwerking, het geheugen, de aandachtsconcentratie, de regulatie van angst, agressie en stemming en van de motoriek en vele andere dysfuncties. Door een dergelijke ontleding krijgt men een indruk van die psychologische functies die in een bepaald geval gestoord zijn en die welke binnen normale grenzen functioneren. Ik heb deze manier van diagnostiseren: functionele psychopathologie 
genoemd en meen dat functionele psychopathologie voor de psychiatrie is, wat de fysiologie is voor de somatische geneeskunde: de methode waarmee men een nauwkeurig inzicht verkrijgt in die componenten van het psychische "apparaat", die dysfunctioneren en in welke mate. Deze kennis verschaft het eenvoudig vaststellen van een psychiatrische "ziekte" niet.

De tweede consequentie van het reactievorm model is, dat het zoeken naar de oorzaak van b.v. de depressie of de schizofrenie zinloos is, omdat de depressie en de schizofrenie, opgevat als discrete ziekte-eenheden, niet bestaan. Een "bassin" van aandoeningen heeft geen eenduidige oorzaak. In de interne geneeskunde wordt ook niet gezocht naar de oorzaak van de groep van buikaandoeningen. Ergo, als het waar is, dat de psychiatrie geen discrete, goed begrensbare ziekte-eenheden kent, zal bij het onderzoek naar de biologische grondslagen van psychiatrische aandoeningen het accent moeten verschuiven van de (veronderstelde) ziekte-eenheden naar dysfunctionerende psychologische domeinen. Niet de biologische determinanten van "de" depressie of "de" schizofrenie moeten het focus van onderzoek zijn, maar de biologische determinanten van psychologische functiestoornissen, waaruit de te onderzoeken psychiatrische aandoening is opgebouwd.

Deze redenering is de grondslag geworden van ons onderzoek naar biologische determinanten van gestoord gedrag en is produktief gebleken. Ik licht dit toe aan de hand van een enkel aspect van ons depressie onderzoek.

\section{Functioneel depressie onderzoek}

Wij waren, zoals gezegd, geinteresseerd in afwijkingen in zenuwbanen die één van de zg. monoaminen als prikkeloverdrager gebruiken, en de rol die deze mogelijk spelen bij het ontstaan van depressies. Wij vonden sterke aanwijzingen dat in de hersenen van sommige depressieve patiënten de huishouding van een bepaalde monoamine, het zogeheten serotonine, inder- 
daad gestoord is, en dat dit leidt tot verminderde activiteit in zenuwcircuits die serotonine als prikkeloverdrager tussen twee zenuwcellen behoeven (Van Praag et al, 1970). Dat deze serotonerge afwijkingen een rol spelen bij het ontstaan van de depressie werd waarschijnlijk, toen wij aantoonden dat een voorstadium van serotonine, het aminozuur 5 -hydroxytryptofaan een verbinding die in de hersenen snel in serotonine worden omgezet - bij dergelijke patiënten een therapeutisch effect en bij chronische toediening een profylactisch effect sorteert (Van Praag en Korf, 1971; Van Praag en De Haan, 1980).

Deze waarnemingen zijn een krachtige stimulans geweest voor de doelgerichte ontwikkeling van een nieuwe klasse antidepressiva, te weten stoffen die de activiteit in serotonine-gestuurde zenuwbanen gericht aanzetten. Ik doel op de groep van de selectieve serotonine opname remmers - een groep waartoe het fameuze fluoxetine (Prozac) behoort. Deze verbindingen worden thans algemeen bij de behandeling van depressies toegepast. Hun ontwikkeling hangt rechtstreeks samen met het klinische onderzoek dat het bestaan van serotonerge stoornissen bij depressies aannemelijk maakte.

Stoornissen in de serotonine huishouding konden wij, zoals ik reeds zei, bij sommige depressieve patiënten wél, maar bij anderen niet aantonen. Het was ons aanvankelijk niet duidelijk waarin die twee groepen klinisch van elkaar verschillen. Hierover werd meer duidelijkheid verkregen toen wij ons onderzoek uitbreidden naar het terrein van de angst- en dat van de agressie-stoornissen. De aanleiding hiertoe was drie-ledig. Ten eerste: versterkte angst en agressie komen bij depressie regelmatig voor. Ten tweede: angst en agressie treden bij psychiatrische aandoeningen veelvuldig hand in hand op. Ten derde: in dierexperimenten was duidelijk geworden dat serotonine-gestuurde circuits in de hersenen een rol spelen bij de regulatie van zowel angst als agressie.

Deze onderzoekslijn bracht enige klaarheid in de kwestie waarom sommige depressieve patiënten wél, andere geen aan- 
toonbare stoornissen in de serotonine huishouding vertonen. De factor angst bleek een belangrijke voorspellende factor te zijn. Vooral bij depressieve patiënten die tevens zeer angstig zijn, bleek de serotonine huishouding gestoord te zijn (Van Praag, 1992a). Er werd nog een tweede voorspeller gevonden: gestoorde agressie-regulatie. Hoe sterker de depressieve patiënt agressieve tendenties vertoont (in de vorm van suïcidaliteit of van naar buiten gekeerde agressie) hoe groter de kans dat serotonerge stoornissen konden worden aangetoond. Åsberg en haar medewerkers (1976) in het Karolinska Instituut in Stockholm waren de eersten die de correlatie tussen serotonine en agressie wereldkundig maakten. $\mathrm{Z}_{\mathrm{ij}}$ waren ons net iets te vlug af geweest, waarvoor overigens niets dan hulde.

Wij kwamen aldus tot de conclusie, dat de serotonerge stoornissen die in eerste instantie geconstateerd waren bij depressies, niet specifiek zijn voor depressie als zodanig, maar gekoppeld zijn aan bepaalde psychologische dysfuncties, te weten gestoorde angst- en agressieregulatie. Angst en agressiviteit kunnen bij depressies uitgesproken of ondergeschikt zijn. Dit verklaart vermoedelijk dat stoornissen in het serotonine-systeem bij depressieve patiënten soms wel, soms niet aantoonbaar zijn.

Indien onze conclusie juist is, mocht worden verwacht dat de geconstateerde stoornissen in het serotonine-systeem eveneens voorkomen bij andere (niet-depressieve) psychiatrische aandoeningen met uitgesproken angst en agressie. Hiervoor zijn inderdaad aanwijzingen gevonden (o.m. Van Praag et al, 1987a, 1987b, 1990; Kahn et al, I988). Serotonerge stoornissen bij psychiatrische aandoeningen bleken nosologische grenzen niet te respecteren.

Een diagnostische urucht van het functionele depressieonderzoek Ik kom nu terug tot mijn uitgangspunt het functioneel psychopathologische denken, het denken in gestoorde psychologische domeinen, als tegenhanger van het nosologische denken, het 
denken in afzonderlijke ziekte-eenheden. Ik constateer, dat de stoornissen in de serotonine-huishouding, die aanvankelijk bij depressies waren geconstateerd, niet specifiek bleken te zijn voor de depressie als zodanig, maar voor bepaalde psychologische dysfuncties, te weten gestoorde angst- en agressie-regulatie, ongeacht de psychiatrische aandoening waaraan de patiënt geacht wordt te lijden. Het denken in ziekte-eenheden bleek een doodlopend spoor te zijn. Het functionele denken daarentegen resulteerde in zinvolle samenhangen tussen gestoorde hersenfunctie en gestoord gedrag.

Ik noem in deze voordracht nog één waarneming die ik beschouw als steun voor het functionele denken in de psychiatric (Van Praag, I996a, I996c). Wij stelden vast, dat bij depressies met gestoorde serotonine-huishouding de depressie zich veelvuldig aankondigt door gevoelens van angst en uitingen van verhoogde agressiviteit (prikkelbaarheid, woede-uitbarstingen, tegendraadsheid e.d.). Stemmingsdaling treedt in dic gevallen pas in een later stadium op. Op deze en andere gronden lanceerden wij de hypothese, dat bij dit type depressie gestoorde angst- en agressieregulatie de kernsymptomen zijn, die pas in tweede instantie een ontregeling van de stemmingsregulatie kunnen oproepen. Het betreft hier dus een type depressie dat geen primaire stemmingsstoornis is. Wij noemden die subgroep van depressie: serotonine-gerelateerde, angst/agressie-geïnduceerde depressie.

Indien deze hypothese juist is, zou de voorkeursbehandeling van dit depressie-type niet een van de gangbare antidepressiva zijn, maar een farmacon dat angst- en agressie-regulatie normaliseert via gericht functieherstel van gestoorde serotonine-gestuurde systemen. Farmaca met een dergelijke werking zijn thans in ontwikkeling. Of zij de door ons veronderstelde preferentiële werking hebben is nog niet onderzocht.

Het idee dat wij lanceerden, impliceert dat de behandeling van de serotonine-gerelateerde, angst-/agressie-geinduceerde depressie niet ziekte-gericht is, maar gericht op normalisatie van 
ontspoorde psychologische functies, waarvan aannemelijk is gemaakt dat zij als gangmaker fungeren van de desbetreffende aandoening. Ik noemde deze therapeutische strategie: functionele psychofarnacologie.

Samenvattend, stel ik vast, dat de functionele wijze van diagnostiseren de psychiatrie in tenminste drie opzichten verrijkt.

I $\mathrm{Zij}$ leidt tot verfijning en verwetenschappelijking van de psychiatrische diagnostiek. Dit laatste, omdat psychologische dysfuncties goed meetbaar zijn, in veel gevallen zelfs kwantitatief. Dit in tegenstelling tot de thans onderscheiden psychiatrische ziekten en het ingewikkelde syndroom (complex van symptomen), dat een bepaalde patiënt vertoont. De ernst dáárvan laat op z'n hoogst een globale schatting toe, in termen als: uitgesproken of licht aanwezig of een gradatie daar tussenin.

2 Zij opent nieuwe, produktief gebleken, wegen voor het biologische psychiatrisch onderzoek, door aandacht te vragen voor de relaties tussen neurobiologische en psychologische dysfuncties.

$3 \mathrm{Zij}$ kan leiden tot een principieel andere farmaco-therapeutische aanpak van psychiatrische aandoeningen. Een aanpak die niet zo zeer ziekte-gericht is, maar dysfunctie-gericht. Een dergelijke koerswijziging in behandelingsstrategie zou, op zijn beurt, tot een fundamentele koerswijziging bij de ontwikkeling van nieuwe psychofarmaca leiden.

Kortom, het betreft hier een denkbeeld, dat waard is verder op z'n merites te worden onderzocht.

\subsection{Enkele organisatorische activiteiten}

Academische psychiatrie als gangmaker in de Geestelijke

Gezondheidszorg

Aldus, in vogelvlucht, enkele onderzoekslijnen en resultaten, die 
- in ieder geval voor m'n eigen denken - verrijkend zijn geweest; bevredigend voor m'n creatieve behoeften en die er sterk toe hebben bijgedragen dat ik studie als één van de zingevers van mijn leven beschouw.

Mogelijkheden iets nieuws te creëren bestaan voor een universitair medewerker niet alleen op wetenschappelijk, maar ook op organisatorisch terrein. Ik heb hieraan, aan het organiseren, het managen, altijd veel plezier beleefd. In Groningen ben ik zo bevoorrecht geweest gevraagd te worden een afdeling Biologische Psychiatrie van de grond af aan op te zetten (1966-1976) ${ }^{3}$. Het was de eerste afdeling van die aard in Europa. In Utrecht maakte ik de uitbouw van een research afdeling binnen de psychiatrische universiteitskliniek - dit in nauwe samenwerking met het Rudolf Magnus Instituut voor Farmacologie - tot één van mijn belangrijke doelstellingen (1977-1982). In Maastricht (1992-1997) werd ik gevraagd om drie tot dan toe zelfstandige vakgroepen binnen het veld van de psychiatrie, bijeen te brengen.

Het was echter gedurende de New Yorkse periode (1982I992), dat ik mijn organisatorische vleugels ten volle heb kunnen uitslaant. Mij was gevraagd om de psychiatrische afdelingen van het Albert Einstein College of Medicine (AECOM) en het Montefiore Medical Center (MMC) - academische afdelingen die tot dan toe volledig gescheiden en onafhankelijk waren - te fuseren en voorts het psychiatrische onderzoeksprogramma uit te bouwen en te intensiveren.

Ik arriveerde in New York en merkte tot mijn verbazing, dat ten aanzien van het unificatieproject geen enkele geschreven richtlijn bestond. Doe het, doe het op jouw manier, maar doe het en kom af en toe verslag uitbrengen. En zo is het gegaan. Het was mijn eerste kennismaking met de typisch Amerikaanse aanpak om bij structuurveranderingen primair improviserend te werk te gaan en de regelgeving pas in tweede instantie te laten volgen en te enten op de praktijkervaringen. In Nederland bewandelt men gewoonlijk de omgekeerde weg. Ik vind de 
Amerikaanse werkwijze verfrissend en stimulerend, en de Nederlandse vaak traag en moeizaam.

De unificatie verliep volgens de plannen die ik en mijn medewerkers ontwierpen. De leiding van AECOM en MMC hadden een fusie voor ogen op academisch niveau. Wij, echter, waren van oordeel dat de unificatie daarenboven een unieke kans bood tot vorming van een hecht, samenhangend netwerk van praktische voorzieningen onder de koepel van een academische afdeling psychiatrie. Deze visie werd in praktijk gebracht. Zo werd de academische psychiatrie binnen AECOM/MMC (en de met hen geaffilieerde afdelingen) een organisatic, die én financieel, én organisatorisch én klinisch verantwoordelijk was voor de geestelijke gezondheidszorg in het grootste deel van de Bronx, een wijk van de stad New York met ca. 1.3 miljoen inwoners. Een, ook voor de V.S., unieke situatie die de toenmalige gouverneur van de staat New York, Mario Cuomo, als een "outstanding service to the people of the state of New York" heeft bestempeld.

\section{Innovatie in de opleiding tot psychiater}

Ook op het terrein van de opleiding tot psychiater was mijn afdeling in New York gespitst op nieuwe mogelijkheden. Zo opteerden wij voor, en werden uitgekozen als één van de zes afdelingen psychiatrie in de V.S. die werden uitgenodigd een nieuw type opleiding op te zetten, het zogeheten Triple Board Program. Binnen dit programma wordt de arts-assistent getraind in de psychiatrie, de kinderpsychiatrie en de kindergeneeskunde en mag op deze drie gebieden het specialisten-examen afleggen. Zo werd een nieuwe medische hybride geschapen en werden klassieke medische scheidslijnen doorbroken. De opleiding werd een succes en is enige jaren geleden officieel erkend door de psychiatrische en pediatrische specialisten-verenigingen.

Een ander innoverend initiatief was de resurrectie van de opleiding in de neuropsychiatrie. Onze afdeling opende een 
neuropsychiatrische unit waar alle assistenten in de psychiatrie een stage lopen en initieerde een programma voor het behalen van een speciale aantekening neuropsychiatrie. Ondanks de aanvankelijk sombere voorspellingen van een deel van de staf, genoot de stage neuropsychiatrie bij de assistenten vanaf het begin een grote populariteit ${ }^{5}$.

\section{Research organisatie}

De onderzoekszwaartepunten van het Albert Einstein College of Medicine liggen op het terrein van de neurowetenschappen en het kankeronderzoek. Opgenomen in een omgeving met een zo hoge concentratie van hersenonderzoekers was het ronduit een genot een biologisch-psychiatrisch onderzoeksprogramma op te bouwen. Ik heb een duidelijk accent gelegd bij het preklinische basisonderzoek, omdat biologische psychiatrie niet goed gedijt, als het die fundamentele voedingsbodem ontbeert. Met de hulp van velen slaagde die opzet. Toen ik kwam was er binnen de psychiatrie één neurobiologisch lab, toen ik vertrok waren het er zes.

Het klinisch onderzoek werd overigens allerminst verwaarloosd. Er kwam een uitgebreid depressie- en schizofrenieprogramma van de grond met zowel biologische, psychologische als psycho-sociale componenten. Door het bijna dagelijkse contact met een zo grote en zo gedifferentieerde groep van onderzoekers werd de Amerikaanse periode tot een hoogtepunt in mijn loopbaan. ${ }^{6}$

\subsection{De lof van het presieren}

Studeren, onderzoeken, initiëren als zingever van een bestaan. Ik kan het ook anders zeggen. Mijn leven is prestatie-gericht geweest. Dit is een instelling die in Nederland aan het einde van de zestiger jaren en nog vele jaren daarna niet "salonfähig" was. 
De idee van de gelijkwaardigheid der mensen vierde hoogtij en gold als bij uitstek progressief. Het begrip gelijkwaardigheid omvatte, terecht, de notie van gelijke rechten en gelijke kansen voor eenieder, maar tevens en abusievelijk de notie van gelijkheid qua capaciteiten en qua geneigdheid die, doelgericht, te bundelen en in te zetten. Om deze visie te rechtvaardigen werd (intellectuele) taptemelk tot norm verheven en werden vollemelk- produkten van de markt geweerd.

Een dergelijk klimaat leidt tot regressic naar het gemiddelde, of beter: tot regressie naar de middelmaat. Het is een klimaat geschikt om de intellectuele ruggegraat van een samenleving te breken. Ergo, een opvatting, die ik beschouw als regressief en dus als reactionair, werd verpakt in een progressieve emballage. Andermaal een voorbeeld van een waarde-omkering met negatieve maatschappelijke effecten.

Ik heb de tijdgeest maar getrotseerd, omdat voor mij studeren, onderzoeken en organiseren belangrijke smaakmakers en daarmee zingevers van mijn leven zijn. Daar komt nog een element bij. Onderzoek schept een "extended family". Je werkt dag in dag uit samen met een groep collega's die elkaars nieuwsgierigheid delen, die gelijke intellectuele "belangen" hebben en complementaire capaciteiten. Nergens beleef je de groepssfeer zo indringend als in een goed functionerende, produktieve researchgroep. Groepssfeer definieer ik als positief beleefde, wederzijdse afhankelijkheid. Ik heb ervan genoten en zal het missen. 


\section{Derde zingever: Het Jodendom}

\section{I Het principe}

De derde zingever in mijn leven is het Jodendom. Het is de gemeenschap waartoe ik behoor; het is mijn bakermat. Zonder navelstreng naar het verleden zou ik in te ijle lucht leven. Ik ben, ik heb dat hiervoor al aangeduid, een groepsmens. Niet in de zin dat ik moeilijk met mezelf alleen zou kunnen zijn, maar omdat ik me graag omgeven weet door geest-verwanten en lotgenoten.

Voor de historie van de Joden heb ik ontzag. $\mathrm{Zij}$ is een indrukwekkend getuigenis dat onderdrukking kan falen zelfvertrouwen te breken; dat trots op eigen identiteit immuun kan zijn voor vernedering; dat creativiteit kan floreren in een barbaars klimaat. De geschiedenis van de Joden inspireert tot optimisme en geloof in de toekomst. Studie genereerde de wil tot overleven, tegen de verdrukking in. De heiligheid van het studiemateriaal was zonder twijfel een krachtige versterker van de hoop, maar boven alles demonstreert de geschiedenis van de Joden de betekenis van studie als vrijhaven van de geest, waar een leven dat anderszins uitzichtsloos en grauw zou zijn, kleur aanneemt en inhoud krijgt.

Bovendien vertegenwoordigt het Jodendom spirituele waarden die mij dierbaar zijn. Wanneer ik zeg Jodendom, dan doel ik zowel op Godsdienst, als op gewoonten en gebruiken, op cultuur. Wat mij in die Godsdienst boeit is de volkomen transparantie, de ontstoffelijking van het Godsbegrip. "Gij zult U geen gesneden beeld maken noch enige gestalte van wat boven in de hemel is" (Exodus 20:4). Maimonides (Moses ben Maimon), de grote rabbijn en geleerde uit de ize eeuw, formuleerde het aldus: "I believe with perfect faith that the Creator, blessed be $\mathrm{His}$ name, is not a body, and that $\mathrm{He}$ is free from all the accidents of matter, and that He has not any form whatsever" (In: Keller, I992). God vertegenwoordigt het alom en altijd zijn- 
de, maar is tegelijk een abstractie, ondeelbaar, onherleidbaar en zintuiglijk onherkenbaar. De Joodse Godsdienst heeft de monotheistische idee geintroduceerd en in zuivere vorm gehandhaafd.

Een tweede punt dat me aantrekt in het geloof der Joden is, dat het, paradoxalerwijs, een godsdienst is zonder theologie. Het kent nauwelijks iets dat zweemt naar dogmatiek, behoudens dan het geloof in één, ondeelbare God. Het kent geen artikelen waarin de essentie van de Godsdienst is samengevat en waarin geloofd moet worden teneinde voor geloofsgenoten acceptabel te zijn en uiteindelijk genade deelachtig te worden.

Wat het volk op de berg Sinaï verwierf, was niet een dogmatiek, maar een wetgeving en een ethische code; een reeks instructies en voorschriften, waaraan men zich hier op deze aarde dient te houden, opdat men, hier op deze aarde, geluk en voorspoed deelachtig wordt. Er werd niet gezegd: dit zult u geloven en dit nalaten te geloven; er werd gesteld: u zult dit doen en dat nalaten. "Wij zullen doen en luisteren naar wat de Almachtige heeft gezegd" (Exodus 24.7), antwoordde het volk toen Gods voorschriften werden geopenbaard. Die reactie behelst voor Joden de kern van het Godsdienstig engagement (Peli, 1988). Niet gedwee maar vrijblijvend volgen, niet luisteren zonder te horen, maar actieve inzet om de ethische code te effectueren.

De ondergesschiktheid van de dogmatiek schiep ruimte voor exegese en interpretatie. De Joden werden het volk van het woord; én door hun gerichtheid op discussie en dialectiek én omdat zij hun religieuze monumenten niet uit steen maar uit woorden optrokken.

Vooral de moraalcode die dit volk zo'n 2500-3000 jaar geleden optekende en van een goddelijk imprimatur voorzag, is mij lief. "Rechtvaardigheid, rechtvaardigheid zult gij najagen, opdat gij leven zult" (Deuteronomium 16: 20) en "Heilig zult gij zijn, want ik, God uw Heer, ben heilig" (Leviticus Ig:1,2). Hoe is het in Godsnaam mogelijk, dat een volk van woestijnnomaden en voormalige slaven de ethische essentie van het menselijk be- 
staan zo universeel heeft kunnen formuleren? Geen literator, en geen literaire school heeft het morele imperatief van de mens zorg hebben voor elkaar -- zo indringend en in zo'n sublieme taal te boek gesteld als de Profeten. Zij behoren tot mijn lievelingsliteratuur.

Begrijp me goed: ik maak geen enkele aanspraak op enigerlei heiligheid, maar ik acht het wel essentieel om de Gouden Standaard te kennen en mijn feitelijk gedrag hieraan af te meten. Ik noem dat zelfkennis.

Zoals mijn gezin zin verleent aan de toekomst, de studie aan het heden, zo is het Jodendom voor mij de zingever van het verleden.

\subsection{De praktijk}

In mijn ouderlijk huis speelde religie geen grote rol. Ik kom uit een areligieus gezin. Ik heb, achteraf gezien, dat facet van het leven wel gemist. Het was een andere expressievorm van het Jodendom dat thuis centraal stond: het nationalistische. Mijn grootouders van beide zijden, behoorden tot de eerste zionisten. Ook mijn ouders waren actief in de beweging die de staatkundige herrijzenis van het Joodse volk voorstond. Ik deelde die overtuiging, met overtuiging. I $\mathrm{k}$ voelde het als een plicht naar Palestina, het latere Israël te gaan en bij te dragen tot de opbouw van die staat. "Mijn tong kleve aan mijn verhemelte als ik $U$ niet gedenk; als ik Jeruzalem niet verhef boven mijn hoogste vreugde" (Psalm 137). Ik heb Jerusalem niet vergeten; ik heb haar, zo voel ik dat wel, verzaakt. Het is een aspect van m'n leven waarop ik niet trots ben.

Ik ben niet gegaan, en toen in 1948 de staat Israël was opgericht concludeerde ik dat ik me geen zionist meer kon noemen. Een zionist gáát; de tijd voor lippendienst aan Zion is voorbij. Ik ging niet en er waren redenen voor, al overtuigden ze me niet tenvolle en nog steeds niet. 
In 1945 teruggekomen uit de Duitse concentratiekampen, wilde ik allereerst zo snel mogelijk een einddiploma middelbare school behalen. Zo werd het 1948 . Ik stelde vast, dat ik nu allercerst arts wilde worden. Zo werd het 1956 en moest ik tot 1958 in militaire dienst. Vervolgens kreeg ik een assistentschap in de neurologie en psychiatrie aangeboden, in een periode dat dergelijke posities schaars waren. Ik aanvaardde het aanbod, specialiseerde en promoveerde en zo verstreken nogmaals 5 jaren. Na de specialisatie was ik enkele jaren chef de clinique van de afdeling Psychiatrie van het Dijkzigt Ziekenhuis in Rotterdam, met als zelf-rechtvaardiging dat ik klinische en organisatorische ervaring op moest doen. Toen kwam in 1965 het aanbod naar Groningen te komen om een afdeling Biologische Psychiatrie op te zetten, en dat met ruime financiële mogelijkheden. In 1968 werd ik lector, 2 jaar later hoogleraar biologische psychiatrie. De afdeling floreerde. De functic was zo aantrekkelijk, bood zoveel mogelijkheden en was zo uniek in een tijdvak dat psychiatrische afdelingen nog maar nauwelijks faciliteiten bezaten voor famacologisch, biochemisch, fysiologisch en diergedragsonderzoek, dat Israël wederom werd uitgesteld.

Zo werd het 1976 . In dat jaar bereikte mij een uitnodiging, die de uitnodiging van m'n leven had kunnen zijn, namelijk om hoogleraar Psychiatrie te worden en Hoofd van de Afdeling Psychiatrie van het Academische Ziekenhuis Hadassah van de Hebreeuwse Universiteit te Jerusalem. Ik vertrok nog datzelfde jaar; als gasthoogleraar, omdat ik om een proefperiode had verzocht. Ik ging direct; zonder m'n familie omdat m'n oudste zoon voor z'n eindexamen middelbare school zat. Dat is een psychologische fout geweest, omdat ik me zo de dagelijkse familiesteun ontzegde. Ik had die nodig. Mijn problemen met de taal waren kolossaal en ik twijfelde of ik in Israël ooit als psychiater zou kunnen functioneren ${ }^{6}$. Op het allerlaatste moment er was met steun van de Universiteit al een huis voor ons gekocht - besloot ik het aanbod af te slaan. Het was de meest emotioneel beladen beslissing van m'n leven. Ik realiseerde me 
later, dat het taalprobleem, m'n beslissing nog op een andere manier had bepaald. De jaren nodig om de taal te leren beheersen zouden ten koste zijn gegaan van m'n onderzoeksinspanningen. Ik had die prijs kennelijk te hoog gevonden. Het is een zelfzuchtige beslissing geweest.

Ik verliet Jerusalem, aanvaardde een algemeen Hoogleraarschap Psychiatrie in Utrecht en voelde me een halve deserteur. Vier jaar later in 198I werd ik uitgenodigd door het Albert Einstein College of Medicine in New York voor de functie van Hoogleraar Psychiatrie en Hoofd van de te fuseren afdelingen Psychiatrie van het Albert Einstein College of Medicine en Montefiore Medical Center. Het Albert Einstein College of Medicine is een Medical School verbonden aan Jeshiva University, de enige Joodse universiteit buiten Israël. Ik nam de uitnodiging aan, zonder veel aarzeling; niet alleen omdat het een eervolle uitnodiging was, maar omdat ik Einstein en de Joodse gemeenschap in New York als "little Jerusalem" beschouwde. Die verwachting is uitgekomen. New York is niet alleen wetenschappelijk en organisatorisch, maar ook spiritueel het hoogtepunt van m'n leven geworden.

Maar toch, de vraag of het ware Jerusalem niet de betere keus zou zijn geweest, heeft me niet meer losgelaten.

\section{$5 \quad$ Epiloog}

Ik ben aan het slot gekomen van mijn rede, maar wil nog één penseelstreek aan dit zelfportret toevoegen.

Ik ben in zekere zin een religieus mens, al belijd ik een eigenzinnig soort Godsdienst, een soort privé Godsdienst. Ik zeg u dit, om de zin van mijn slotwoorden te verhelderen. Ik beschouw mezelf als gelovig, in die zin dat ik God zie als zinnebeeld van de meest nobele, de meest creatieve en sublieme aspiraties en intenties die de mensheid - in z'n beste vertegenwoordigers, in hun beste momenten - genereert. "De 
menselijke ziel is Gods lamp", luidt een van de Spreuken (20:27). Het is alleen in dat licht, dat de schoonheid en de waardigheid van $\mathrm{Zijn}$ aanschijn zichtbaar wordt.

Dit credo moge verduidelijken wat ik bedoel met mijn slotclaus, bedoeld voor $\mathrm{u}$, toehoorders, maar zeer speciaal voor mijn medewerkers over de jaren. $\mathrm{Zij}$ die hier aanwezig zijn en zij die dat niet (meer) konden.

Ik dank u voor de samenwerking, maar boven alles voor uw vriendschap en loyaliteit. Moge het u gegeven zijn licht te laten schijnen op Gods aanschijn.

Met deze woorden is het stuk ten einde en kan het doek vallen. Althans voor nu. Ik heb het laatste woord nog niet gezegd. Ik voel me nog niet uitgespeeld; ik ben nog niet uitgepraat. Om de titel van een lied van Paul Simon te parafraseren: "I am still moving after all these years". Ik hoop in staat te zijn aan het stuk nog een bedrijf te kunnen toevoegen; Deo volente.

Dames en heren, ik heb gezegd. 


\section{Noten}

I Kolonel Beunders, destijds hoofd van de afdeling Preventieve Genecskunde van de Militair Geneeskundige Dienst, had mij uitgenodigd dit onderzock te verrichten, een mogelijkheid dic ik met beide handen aangreep. Ik werkte in Baarn onder leiding van Dr. Gerard de Vries, Hoofd van de afdeling Medische Mycologie. Het werd ecn bijzonder plezierige en vruchtbare samenwerking, die resulteerde in cen aantal studics, dic Prof.dr. H.W. Sicmens, destijds hoogleraar dermatologic in Leiden, als procfschrift acceptcerde. Ik promoveerde nict op dit onderwerp. De tijd ontbrak, omdat ik direct na m'n diensttijd startte met de opleiding in de psychiatric en het prille hersenen en gedragsonderzock.

Mijn tijd in Baarn werd opgeluisterd door mijn contacten met Prof. Johanna Westerdijk, de cerste directeur van dat lab en cen pionicr in de Vrouwen Beweging. Ofschoon in haar nadagen, was de kracht van haar persoonlijkheid nog duidelijk herkenbaar en imponcrend. Ik prijs me gelukkig haar nog gekend tc hebben.

2 Mijn ex libris, dat op pagina 5 staat afgebecld, symbolisecrt deze dric ankerpunten. De zwaan is het zinnebeeld van gebondenheid aan en verbondenheid met het gezin; de twec boeken zijn het zinnebeeld van de studic. De menorah (zevenarmige kandelaar) symbolisecrt de spiritucle kant van het Jodendom; de lecuw (van Judah) de nationalistische. De twee handen op de rug van het linker boek, gespreid op de wijze zoals dat geschicdt bij het uitspreken van de priesterzegen, waren het kenmerk van de boeken gedrukt en uitgegeven door de firma Proobst, het beroemde Amsterdamse uitgevershuis van Joodse en Hebrecuwse boeken uit de $17 \mathrm{e}-18 \mathrm{c}$ ccuw, waarvan onzc familie in rechte lijn afstamt.

3 Twee mannen zijn bij dezc ontwikkeling belangrijk geweest. Professor Kuno van Dijk, destijds hoofd van de Psychiatrische Universiteitskliniek in Groningen en dc tocnmalige medisch curator van het College van Curatoren van de Groningse Universitcit: Dr. Dijkhuis. De psychoanalyticus Van Dijk en de huisarts Dijkhuis, beseften het belang van het biologische onderzock voor $\mathrm{de}$ psychiatric. De eerstc vroeg me naar Groningen te komen, de tweedc stelde de middelen ter beschikking en was hicrbij genereus. Daarom kon de ecrste afdeling Biologische Psychiatric in Europa er één worden met grote reikwijdte. $\mathrm{Zij}$ omvatte niet alleen cen klinische research unit, maar bovendien laboratoria voor biochemisch/farmacologisch onderzock, voor electrofysiologisch onderzoek en voor diergedrags onderzock. De Groningse psychiatric was hicrmec z'n tijd ver vooruit.

4 Het vertrek naar de V.S. is in geen enkel opzicht bepaald door de aanvallen dic de biologische psychiatric in het algemeen en ikzelf wel zeer in het bijzonder, in 
dic dagen in Utrecht te verduren hadden. Ik heb in Utrecht met zecr veel plezier gewerkt en kunnen werken omdat het bestuur van de Faculteit der Geneeskunde (destijds onder leiding van Prof. Rijk Gispen), het bestuur van het Academisch Zickenhuis Utrecht met als medisch directeur Prof.Dr. Borst-Eilers, en de staf van de Psychiatrische Universiteitsklinick zich gehecl achter mijn programma hadden geplaatst. Het soms letterlijk oorverdovend, rumoer schalde in de marge. De fysicke bedreigingen hadden een politicke achtergrond; die politick verfocide ik, zowel qua vorm als qua inhoud, maar dit was geen reden om de strijd op te geven. Integendecl, wecrstand sterkt mijn wil en vermogen door te zetten (zie ook mijn interview met David Healy in: The Psychopharmacologists. Interviews by David Healy, Chapman and Hall, London, 1996).

De invitatie om Hoofd te worden van Einstein's afdeling Psychiatrie, beschouwde ik als ecn cervolle; de expliciete opdrachten: "versterk de research en verenig de afdelingen Psychiatrie van Einstein en Montefiore!", als boeiend en stimulerend. Dát waren de redenen voor mijn vertrek naar de V.S.

5 Een ander initiaticf mislukte: Ik had graag ecn z.g. "med./psych. unit" opgericht, waarin patiënten met interne en psychiatrische zicktebeclden gemecnschappelijk door internist en psychiater worden onderzocht en behandeld. Aan een dergelijke unit zou ecn dubbele opleiding tot internist en psychiater kunnen worden gekoppeld, in analogic met het genoemde Triple Board Program. Door gebrek aan belangstelling bij de internisten, licpen deze plannen op niets uit.

6 Ook voor de mentaliteit van de Amerikaan heb ik respect. Het zijn (in het algemeen) harde werkers, aanpakkers, moedige mensen ook. Moedig omdat het land, in vergelijking met het onze, weinig sociale zekerheden biedt. Je pakt aan, ook al valı het zwaar, of je glijdt gemakkelijk af naar de status van underdog. Desondanks houdt men van z'n land, z'n geschicdenis, z'n tradities, z'n cultuur, z'n prestatics, en komt daar graag voor uit. Nationaal zelfrespect wordt niet verward met bekrompen chauvinisme.

In mijn rede ter gelegenheid van mijn vertrck van het Albert Einstein College of Medicine drukte ik mijn gevoelens over Amerika als volgt uit:

"Indecd, this is a nation, both awcsome and awc-inspiring.

Thinking about America, two images come to my mind: the bison and naturc as it reveals itself in Bryce National Park. Together, these symbols represent for me the best of the ingredients the American society is made of.

The bison symbolizes determination; self-confidence; purposefulness; relentlessness; stubbornness; aggressiveness; strength, individual strength and even more, collective strength exploding when these individuals assemble as a group, coalescing as a unity despitc substantial individual differences. 
Bryce was for me a stunning experience; an Amcrican cxperience. A fantastic world, full of fanciful forms, secmingly uniform; however, at close look, cach of them unlike the other; apparently airy and light footed; at close range, however, sturdy and solidly anchored in the real world. A world of boundless creativity and thus, of unlimited opportunity.

I realize that explanation of symbols is precarious. It is their very essence that they transcend translation in the vernacular, to express a vision more trenchant than a line of argument can. I approximated thcir meaning to cxpress that it has been a truc privilege to try in my own way, to make a small contribution to this great socicty."

Mijn besluit Amerika te verlaten was ambivalent. Ik lict Amerika achter me, maar herwon Europa. Ik verloor een bruisende, ondernemende maatschappij; ik won cen leefomgeving met het karakter van ecn historische schatkamer en onverminderd creatief vermogen. Ik verloor een stad dic een van de belangrijkste culturele en wetenschappelijke krachtcentrales van de wereld is, waar ik me als een vis in het water voclde. Ik won een stad van ongekende schoonheid, met hartelijkc emotionele inwoners, waar ik me al gauw thuis, op m'n gemak en culturecl en wetenschappelijk bevredigd voelde.

7 Ondanks de taalproblemen heb ik in Jerusalem met erg veel plezier gewerkt en samengewerkt met een aantal getalentecrde research-georiënteerde psychiatrische assistenten, met name: Jossic Zohar, Bernard Lerer en Uriel Halbreich en met Chajiem Belmaker dic toen pas benoemd was tot hoofd van de research afdeling van ecn met het Academische Zickenhuis Hadassah geaffilieerd psychiatrisch zickenhuis in Jcrusalem. In Einstein werd die samenwerking voortgezet. Wij hadden fondsen voor tien research fellowships van twee jaar in de biologische psychiatrie. Een vrij groot aantal Israeli's heeft in de periode dat ik in New York werkte, van die mogelijkheid gebruik gemaakt. 


\section{Literatuur}

Apter, A., Kotler, M., Sevy, S., Plutchik, R., Brown, S.-L., Foster, H., Hilbrand, M., Kan, M.L., Van Praag, H.M. (1991) Correlates of risk of suicide in violent and nonviolent psychiatric patients. Am J Psychiat 148, 883-887.

Åsberg, M., Thoren, P., Träskman, L., Bertolsson, L. and Ringbergen, V. (1976) "Scrotonin depression" - a biochemical subgroup within the affective disorders? Science $191,47^{8-480}$.

Heschel, A. J. (1955) God in search of man: a philosophy of Judaism. Farrar, Straus and Giroux, New York.

Kahn, R., Van Praag, H.M., Wetzler, S., Asnis, G.M. and Barr, G. (1988) Scrotonin and anxicty revisited. Biol Psychint 23, 189-208.

Moses ben Maimon. Thirtecn principles of faith. In: The Jewes in literature and art. Ed: S. R. Kcller. Köncmann Vcrlagsgescllschaft, Köln, 1992.

McLanahan, S. and Sandefur, G. (1994) Growing up with a single parent. Harvard University Press, Cambridgc, Mass.

Peli, P.H. (1988) De Torah vandaag. J.H. Kok, Kampen.

Plutchik, R. and Van Praag, H. M. ( 1987$)$ Interconvertibility of five self-report measures of depression. Psychial Res 22, 243-256.

Plutchik, R., Van Praag, H. M., Conte, H. R. and Picard, S. (1989) Correlates of suicide and violence risk. I. The suicide risk measure. Compr Psychial 30, 296-302.

Thompson, A. E. and Kaplan, C. A. (1996) Chilhood Emotional Abuse. British Joumal of Psychialy 168, 143-148.

Van Praag, H. M. (1962) Een kritisch onderzock naar de betekenis van monoamineoxydase-remming als therapeutisch principe bij de behandeling van depressies. Proefschifl, Rijksuniversiteit Utrecht.

Van Praag, H. M. (1982a) A transatlantic view of the diagnosis of depression according to the DSM III. I. Controversics and misunderstandings in depression diagnosis. Compr Psychiat 23, 315-329.

Van Praag, H. M. (1982b) A transatantic vicw of the diagnosis of depressions according to the DSM III. II. Did the DSM III solve the problem of depression diagnosis? Compr Psychiat 23, 330-337.

Van Praag, H. M. (1992a) About the centrality of mood lowering in mood disorders. Europ Neuropsychopham 2, 393-402.

Van Praag, H.M. (1992b) Make Believes in Psychiaty or The Perils of Progress. Brunner Mazel, New York.

Van Praag, H.M. (1992c) Reconquest of the subjective. Against the waning of psychiatric diagnosing. Brit 3 Psychiat $\mathrm{r} 60,266-271$.

Van Praag, H. M. (1996a) Scrotonin-related, anxicty/aggression-driven, stressor-pccipitated depression. A psychobiological hypothesis. Eur Psychiat II, 57-67. 
Van Praag, H. M. (1996b) Over the mainstream. Diagnostic requirements for biological psychiatric rescarch. Pyychiat Res in Press.

Van Praag, H.M. (1996c) Faulty cortisol/scrotonin interplay. Psychopathological and biological characterisation of a new hypothetical depression subtype $\mathrm{SeCa}$ depression). Psychiat Res 65,143-157.

Van Praag, H. M. and Leijnsc, B. (1965) Neubewertung des Syndroms. Skizze einer funktionellen Pathologic. Psychial Neurol Neurochir 68, 50-66.

Van Praag, H. M., Korf, J. (1971) Endogenous depressions with and without disturbances in the 5-hydroxytryptamine metabolism: a biochemical classification? Psychophamacologia 19, 148-152.

Van Praag, H.M., De Haan, S. (1980) Deprcssion vulncrability and 5-hydroxytryptophan prophylaxis. Psychiat Res $3,75-83$.

Van Praag, H. M., Uleman, A. M. and Spitz, J. C. (1965) The vital syndrome interview. A structured standard interview for the recognition and registration of the vital depression symptom complex. Psychial Neurol Neurochir 68, 329-346.

Van Praag, H. M., Korf, J. and Puitc, J. (1970) 5-Hydroxindolcacctic acid levels in the cerebrospinal fluid of depressive patients treated with probenccid. Nature 225, 1259-1260.

Van Praag, H. M., Korf, J., Dols, L. C. W. and Schut, T. (1972) A pilot study of the predictive value of the probenecid test in application of 5 -hydroxytryptophan as antidepressant. Psychopharmacologia 25, 14-21.

Van Praag, H. M., Korf, J., Lakke, J. P. W. F. and Schut, '. (1975) Dopamine mctabolism in depression, psychoses and Parkinson's discasc: The problem of the specificity of biological variables in bchaviour disorders. Psychol Med 5, 138-146.

Van Praag, H. M., Kahn, R. S., Asnis, G. M., Wetzler, S., Brown, S., Bleich, A. and Korn, M. (1987a) Denosologization of biological psychiatry or the specificity of 5-HT disturbances in psychiatric disorders. J Affec Disord ${ }^{3} 3,1-8$.

Van Praag, H.M., Kahn, R. S., Asnis, G.M., Lemus, C.Z., Brown, S.L. (1987b) Therapcutic indications for serotonin potentiating compounds. A hypothesis. Biol Psychiat 22, 205-212.

Van Praag, H. M., Asnis, G. M., Kahn, R. S., Brown, S. L., Korn, M., Harkavy Friedman, J. M. et al. (1990) Monoamines and abnormal behavior. A multiaminergic perspective. Brit J Psychiat 157, 723-734. 